\title{
Causal Relationship between Economic Factors and Mortality
}

\author{
By OIVA TURPEINEN \\ University of Helsinki \\ Department of History
}

The rapid growth in the European population, beginning in the 1700 s, has traditionally been explained in two ways. The first explanation, the classic presentation of which was given by G. T. Griffith, is based on the assumption that the decline in mortality played a central part. According to the second point of view, an increased demand for labor led to larger families.

The latter model closely unites population growth and economic factors. In the former approach the situation is much more complicated. A decline in mortality need not necessarily be connected with economic factors. In the classic model this was done, however, as it was industrialization which was seen as the cause of the decline. And it is true, of course, that in England industrialization and the decline in mortality did, at least partially, go hand in hand. However, the problem is whether there is any causal relationship between these two phenomena. ${ }^{1}$

Attempts at covering this problem have been made in several different studies in many European countries, but especially in England. The main difficulty has been the lack of reliable population statistics. In England, the pioneer of modern European industrialization, the systematic registration of population changes and population size began later than the transition from an agrarian economic system to industrialization. These incomplete sources form a bottleneck when examining the problem.

1 For more on the problem, see the following literature among others: G. T. Griffith, Population Problems of the Age of Malthus (1926), T. H. Marshall The Population Problem during the Industrial Revolution. Econ. J. Supplement (January 1929). For a more recent examination of the problem, see e.g. D. E. C. Eversley, Population, Economy and Society (in Population in History, 1965), especially pages $52-56$ and the literature there mentioned. At the end of the $1960 \mathrm{~s}$ and in the 1970 s the matter has been quite widely discussed, see e.g. Population and Economics, Proceedings of Section V of the Fourth Congress of the International Economic History Association 1968 (ed. by Paul Deprez) especially pages 1-93; Population in Industrialization 1969 (ed. by Michael Drake); N. L. Tranter, Population since the Industrial Revolution (1973); Arthur E. Imhof - Øivind Larsen, Sozialgeschichte und Medizin (1975) and the last mentioned text's bibliography, which is especially useful as an orientation to the problem in the Nordic countries. For Finnish studies which touch on the problem, see e.g. Oiva Turpeinen, Kainuun väestöolot ja niihin vaikuttaneet tekijät vv. $1890-1910$ (1967, licentiate study, University of Helsinki); Aarno Strömmer, Väestöllinen muuntuminen Suomessa 
The situation is completely different in Finland, where industrialization began relatively late, but where the registration of statistics concerning the population began in a relatively early phase. Finland, as a peripheral country situated in the marginal agricultural zone, is in this respect an ideal study unit.

In principle, the problem of how economic factors and mortality are connected with each other can be approached from three different viewpoints. First, one can analyze how mortality, on the one hand, and regional differences in prosperity, on the other, are connected. In examining the situation in Finland in the period between 1816-65, I came to the surprising conclusion that the positive correlation between economic prosperity and mortality was very slight (Turpeinen 1973). In the second approach to the problem the mortality of social groups differing in prosperity level is examined. In a Swedish doctoral dissertation analyzing pre-industrial society one can note that at times mortality was even smaller in the lower social groups than in the higher social groups (Winberg 1975, 242-43). The third way to shed light on this important problem is to use a longitudinal analysis. This method will be applied in the study at hand. We will limit the problem, however, so that we will not be examining how swings in mortality in the pre-industrial period were connected to, for example, years of crop failure, instead we will concentrate on how industrialization in Finland and age-group changes in mortality were connected to each other.

In Finland the beginning of industrialization can be placed in the $1870 \mathrm{~s}-$ $1880 \mathrm{~s}$. Population tables give information beginning already in the middle of the 18th century, so that the length of the pre-industrial period is thus about 120 years and the industrial period - our examination will reach to the year 1970 - about 100 years. We thus have an excellent opportunity for making comparisons.

The main source used in our study consists of the population and population change tables, which, for the period preceding 1808, are kept in the Swedish Central Bureau of Statistics and from the year 1808 on in the Archives of the Finnish Bureau of Statistics. ${ }^{2}$ Information on age-specific mortality in the period after 1865, covering all of Finland, is also available in printed form (Statistical Central Bureau, Väkiluvuntilasto VI).

Using this material we have calculated age-specific mortality rates for a

(1969); E. Jutikkala and M. Kauppinen, The Structure of Mortality during Catastrophic Years in a Pre-Industrial Society (Population Studies Vol. XXV, N:o 2 1971); Oiva Turpeinen, Suomen väestöolot vv. 1816-65 (1972, mimeograph), Yrjö Kaukiainen, Miksi kansa lisääntyi, Historiallinen Aikakauskirja 2/1973.

2 Information on the years 1807 and 1814 are missing for all of Finland and on the year 1818 for the Turku diocese. Figures for the last two years mentioned were found by interpolation. This method was not used for the year 1807 , however, because mortality was exceptionally high in 1808 . The mortality figure for the year mentioned was found by calculating the average of the previous five years. 
period covering 220 years. In order to compare mortality in different age groups at different periods of time, classification must be uniform. One unified system is to group ages into five-year periods. In addition, the 0-4-year-old group can be divided into three parts: under 1-, 1-2- and 3-4-year-olds.

How reliable is this information found in official records? Most in doubt is the registration of the youngest age groups. It can be assumed that deaths taking place at the age of a few hours, a day, a week or even a month were not always recorded, especially if the child died unbaptized. Another problem is the still-born.

Criticism of the source of information coming from registers has been analyzed very little. Pitkänen's study, however, which examined the reliability of population data of an Eastern Finnish parish in the years between 1720 and 1880 , shows that the further back in time one goes, the more incomplete are the data (Pitkänen 1975). The research situation is still open as to how far one can generalize about all of Finland on this basis. If the figures for the whole of Finland were also incomplete, this would mainly affect figures on infant mortality and the total death rate, making both series of figures, but especially the former, greater in reality than what is shown by registered events. This criticism of the source material must be taken into account when we draw conclusions in the following about the development of age-specific mortality and its connections with the industrialization of Finland.

In Finland there were, between 1751 and 1970, 8407300 registered deaths, which form the basic data of this study. ${ }^{3}$ In examining the general development one can clearly see - in the table below - that mortality has greatly declined and the mean expectation of life at birth has lengthened dramatically. The former has dropped from 28,0 per thousand at the end of the 18 th century

\begin{tabular}{lcc}
\hline & $\begin{array}{c}\text { Total mortality } \\
\text { rate }\end{array}$ & $\begin{array}{c}\text { Mean life expectancy } \\
\text { (in years) at birth }\end{array}$ \\
\hline $1751-1800$ & 28,0 & 34,7 \\
$1801-1850$ & 26,5 & 35,7 \\
$1851-1900$ & 24,3 & 38,5 \\
$1901-1950$ & 15,9 & 50,8 \\
$1951-1970$ & 9,4 & 68,5 \\
\hline
\end{tabular}

to 9,4 in $1951-1970$. The latter, in turn, has risen in the same period of time from 34,7 years to 68,5 years.

This is the total picture. But when the 8,4 million deaths mentioned are

3 A detailed developmental analysis of mortality in Finland in the years 17511970, by year and age group, is included in my study titled »Ikäryhmittäinen kuolleisuus Suomessa vv. 1751-1970. Demometrinen selvitys» (1973). The original manuseript of the aforesaid study is kept in the archives of the Population Research Institute Helsinki, (Kalevank. 16 A) where it is available to anyone wanting to make a closer study of it. 
examined by five-year periods - the detailed numerical data is shown in the tables in the Appendix (p. 44-45) - , a fact already known to Finnish historical researchers, that is, that after the high mortality rate at the end of the $1860 \mathrm{~s}$ came 21,7 per thousand in $1871-75$, which was the lowest five-year reading since 1750 . And this low mortality rate was no random, temporary phase, but rather the beginning of a permanent decline. In the following four five-year periods the mortality rate measured between 20 and 22 per thousand and then dropped even lower than the firstmentioned value. In the 1900 s the mortality rate continued to decline, so that at the middle of the century it was around 10 per thousand.

Does this not show beyond dispute that the decline in mortality has been a result of industrialization? Traditionally this has been the interpretation, in other Western countries as well as in Finland. In reality, however, development is not this simple or straightforward. This can be seen clearly when examining the development of mortality factors.

Infant mortality. Because the number of deaths at under one year of age in $1751-1800$ was 31,9 percent, in $1801-185026,9$ percent and even in 1851$190023,7 \%$ of the total number of deaths in each 50 -year period, this factor plays a great role in the total picture of mortality.

The total development of infant mortality in Finland has been the following:

\begin{tabular}{|c|c|c|}
\hline & $\begin{array}{c}\text { Number } \\
\text { who died under } 1 \text { year } \\
\text { of age }\end{array}$ & $1751-1800=100$ \\
\hline $1751-1800$ & 217,6 & 100 \\
\hline $1801-1850$ & 197,5 & 91 \\
\hline $1851-1900$ & 164,9 & 76 \\
\hline $1901-1950$ & 91,4 & 42 \\
\hline $1951-1970$ & 23,1 & 11 \\
\hline
\end{tabular}

When looking over the figures one can see that there was a quite definite drop in infant mortality already in the beginning of the 1800 s. In addition, one must bear in mind that coming into the 1800 s from the 1700 s the drop apparently was even greater, if the previously mentioned assumptions criticizing the sources are valid. However, the difference is somewhat smaller in that the comparison is made in regard to the number of registered births, which is also smaller than the actual number, if the assumption on the registration of deaths is valid.

In examining development by five-year periods - see the Appendix table - one can see that the infant mortality rate in $1871-75$ was 170,2 , in other words smaller than ever before. This, along with the other figure, shows beyond a doubt that infant mortality dropped at the same time as industrialization began its take-off phase. However, it is very difficult to join these two phenomena into a causal relationship. For example, we cannot explain why 
infant mortality began to drop already in the 1700 s. Now, of course, researchers who see economic factors and mortality as closely linked, claim that the beginning of the drop in infant mortality can be explained by the arrival of the potato into the diet. ${ }^{4}$ And in the same breath they can say that industrialization was only an additional economic factor which accelerated the declining trend in infant mortality.

Even if we take this additional factor into account, we unfortunately cannot accept this explanation. The development of mortality in the other age groups topples such ideas.

1-2- and 3-4-year-olds. The general development of these two age classes shows - in the table below - that there was no rapid decline in mortality in

\begin{tabular}{lcc}
\hline & $\begin{array}{c}\text { Per } 1000 \text { persons of the average number of } \\
\text { population in the age groups in question }\end{array}$ \\
\cline { 2 - 3 } & 1-2-year-olds & $3-$ 4-year-olds \\
\hline $1751-1800$ & 58,5 & 28,2 \\
$1801-1850$ & 56,2 & 27,2 \\
$1851-1900$ & 55,5 & 26,7 \\
$1901-1950$ & 20,3 & 8,8 \\
$1951-1970$ & 1,8 & 0,9 \\
\hline
\end{tabular}

the 1800 s as there had been in infant mortality. A substantial decline did not take place until the $1900 \mathrm{~s}$. When we analyze this development in five-year periods, an interesting fact is uncovered: in $1771-75$ the mortality rate among 1-2-year-olds was 37,6 and among 3-4-year-olds it was 16,8 . In the beginning of the 1800 s mortality did not come even close to such a low figure in either group. A reading below the former figure was not reached until $1901-05$, when the mortality rate was 36,6 and the latter in $1906-10(14,7$ per thousand).

Two conclusions can be drawn from these facts. First, it does not seem plausible that the spread of the potato at the end of the 1700 s and the beginning of the 1800 s would have increased the mortality of the age groups in question. Second, one can take note that the 1870 s did not form a breaking point in the decline of the mortality of these groups. And such a breaking point would be expected if one takes the stand that economic factors, here industrialization, and a decline in mortality are linked. One would then assume that an increasing standard of living and an improving food situation would make themselves felt especially in these age groups, which were no longer nourished at the breast as were infants.

4 This explanation is quite common in recent studies, see e.g. Michael Dray, Population and Society in Norway $1735-1865$ (1969), especially pages $54-66$. 
5-19-year-olds. In these three age groups the development of mortality has a few additional features compared to the previous groups. In the 5-9year-old group there is still a slight decline in mortality in going from the

\begin{tabular}{lccc}
\hline & \multicolumn{2}{c}{$\begin{array}{c}\text { Per } 1000 \\
\text { persons of the average number of population } \\
\text { in the age groups in question }\end{array}$} \\
\cline { 2 - 4 } & $5-9$-year-olds & 10-14-year-olds & 15-19-year-olds \\
\hline $1751-1800$ & 14,6 & 6,1 & 5,8 \\
$1801-1850$ & 14,3 & 6,4 & 6,0 \\
$1851-1900$ & 12,3 & 5,8 & 6,0 \\
$1901-1950$ & 4,7 & 3,4 & 5,6 \\
$1951-1970$ & 0,6 & 0,5 & 0,8 \\
\hline
\end{tabular}

1700 s to the 1800 s, but in the following age groups there is, on the contrary, a slight rise. Mortality in the 15-19-year-old group was actually greater in $1851-1900$ than in the years $1751-1900 .^{5}$ No declining tendency can be observed.

A closer comparison using five-year periods, with the watershed year still being 1870 , shows that previously the lowest mortality reading in the 5-9-yearold group was in $1771-75-8,9$ per thousand - and that not until 1886-90 (8,3 per thousand) was a lower figure reached. Nevertheless, in $1901-05$ a value of 8,8 per thousand was registered.

The drop in mortality among the 10-14-year-olds is situated much later than in the younger groups. Even though the mortality rate went under 5 per thousand in several five-year periods at the end of the 1700 s and the beginning of the $1800 \mathrm{~s}$, it climbed to 5,2 as late as $1901-05$. Not until $1911-15$ was the figure of 4,2 reached, which went below the then record figure of 4,5 dating from $1771-75$.

The situation is even more interesting among the 15-19-year-olds. The mortality rate in $1796-1800$ was 4,5 per thousand. A figure below this was not reached until as late as $1931-35(4,4)$. Thus no declining tendency can be observed around the year 1870. Quite the contrary. For although the rate was 4,7 in $1841-45$, at the end of the 19th century it fluctuated between 5 and 6 and in 1911-15 for example mortality was an even 6 per thousand.

20 -49-year-olds. The development of the 20-24-year-old group was much the same as that of the previous age class. Mortality at the end of the $1800 \mathrm{~s}$ rose somewhat above that of the two previous fifty-year periods. The situation in the other age groups is already somewhat different. In the four five-year

5 The high mortality rates in $1901-1950$ in the five-year age groups among the 15-19-year-olds as well as the older groups up till the age of 50 were caused by the war deaths of 1918 and $1939-45$, which, of course, is not directly related to the problem at hand. 
Per 1000 persons of the average number of population in the age groups in question

\begin{tabular}{rrrrrrr} 
& $20-24$ & $25-29$ & $30-34$ & $35-39$ & $40-44$ & $45-49$ \\
\hline $1751-1800$ & 7,3 & 8,4 & 10,3 & 11,4 & 14,8 & 16,8 \\
$1801-1850$ & 7,5 & 8,4 & 10,0 & 11,9 & 14,7 & 17,5 \\
$1851-1900$ & 7,9 & 8,4 & 9,5 & 10,9 & 13,0 & 15,4 \\
$1901-1950$ & 9,3 & 8,6 & 8,2 & 8,3 & 9,0 & 10,8 \\
$1951-1970$ & 1,2 & 1,5 & 1,9 & 2,7 & 3,9 & 6,0 \\
\hline
\end{tabular}

age groups between the ages of 30 and 50 mortality in $1751-1800$ was somewhat higher than in $1851-1900$.

In analyzing development in five-year periods one discovers that in the $20-$ 24-year-old group the mortality rate in 1796-1800 was only 5 per thousand, and a lower figure was not reached until $1946-50(4,4)$. As late as $1926-30$ the rate was 7,9. It is interesting to note that at the end of the $1700 \mathrm{~s}$ in a total of eight five-year periods the mortality rate of this age group was lower than the last-mentioned figure and in only two periods was it higher.

In examining the developmental picture of mortality among 25-29-yearolds one notices at the end of the 1700 s a reading of 6,3 per thousand in a fiveyear period, a reading which remained the lowest until 1931-35 (6,1). A similar record-breaking low in the 30-34-year-old group took place in 1921-25 and in the following age group in 1891-95. The development of mortality in the two older age groups, however, differs from that of the previous groups. Before 1870 the lowest five-year mortality rate per thousand among the 40 - 44-yearolds and the 45-49-year-olds was in 1796-1800,11,1 among the former and 13,6 among the latter. In both age groups a lower reading was reached in $1871-75,10,1$ among the $40-44$-year-olds and 12,0 in the next age group. In addition it is worth noting that mortality in both groups started a slight decline after this just at the beginning of the 1870 s. In these age groups the beginning of a decline in mortality and the start of industrialization seem to go hand in hand.

The over-50-year-olds. From the age of fifty to the age of sixty-five mortality - the table below - was higher in 175 - 1800 than in 1851-1900. After

\begin{tabular}{|c|c|c|c|c|c|c|c|}
\hline & \multicolumn{7}{|c|}{$\begin{array}{c}\text { Per } 1000 \text { persons of the average number of population in the age } \\
\text { groups in question }\end{array}$} \\
\hline & $50-54$ & $55-59$ & $60-64$ & $65-69$ & $70-74$ & $75-79$ & $80-$ \\
\hline $1751-1800$ & 21,9 & 28,3 & 42,2 & 55,4 & 84,7 & 112,1 & 183,0 \\
\hline $1801-1850$ & 24,0 & 32,3 & 47,9 & 67,9 & 103,8 & 149,3 & 233,7 \\
\hline $1851-1900$ & 20,4 & 27,5 & 39,8 & 60,9 & 93,9 & 140,5 & 223,5 \\
\hline $1901-1950$ & 14,4 & 20,4 & 29,9 & 44,9 & 69,4 & 108,0 & 183,2 \\
\hline $1951-1970$ & 9,4 & 14,5 & 22,7 & 35,9 & 58,3 & 95,8 & 185,5 \\
\hline
\end{tabular}


this the situation changes and the mortality figures at the end of the 18th century are lower than the rates in the last fifty years of the 19 th century.

When we look at the development of mortality among 50-54-year-olds and $55-59$-year-olds, we find that the mortality rates of $1871-75$ are below the record values of the previous five-year periods. Before 1870 the lowest figures were in $1796-1800(17,8)$ and in $1841-45(17,6)$, but in $1871-75$ the rate per thousand dropped to 16,0 . However, it did rise again to 17,4 in the next fiveyear period, but after this it sank to around 15 and 16 and stayed at this level until the turn of the century. Mortality among the 55-59-year-olds developed in the same way. In $1771-75$ the reading was 24,0 , but in $1871-75$ it was 22,8 . In this group also it rose in $1876-80$ to 24,6 , but dropped right after to between 20 and 23 and remained there until 1936-40.

After the age of 65 the mortality curves become quite complicated. An interesting observation is that in $1751-1800$ mortality in all the age groups was lower than in the following two fifty-year periods. The figure also shows that in the 1900 s mortality did not change very much in these age groups. The situation among the over-80-year-olds is about the same in the second half of the 18 th century as it is in the 1900 s.

This general picture already shows that mortality cannot be smoothly linked to industrialization in these groups, either. An examination by five-year periods supports this view, although not unambiguously. For example, the mortality rate of the $65-69$-year-olds in $1871-75$ was 51,4 , which was clearly lower than in the previous five-year period, but nevertheless above the lowest reading in the $1700 \mathrm{~s}$. On the other hand when glancing over the mortality figures one notes the unusually high mortality of $1866-70$ and the fact that the declining tendency did not become permanent in this age group until 18961900. After this the mortality rate remained around 45 per thousand, until a second definite decline took place in 1946-50, to below 40 per thousand. Among the $70-74$-year-olds the respective record lows took place in $1896-1900$, when the mortality rate dropped below 80 and in $1921-25$, when a figure below 70 was reached and again in 1956-60, when mortality dropped "permanently" below 60 per thousand. It is interesting to note that in the $75-79$-year-old group the record lows occurred in the same five-year periods.

The lowest five-year mortality reading among the 70-74-year-olds in the 1700 s was in $1776-80(74,3)$ and among the 75 - 79 -year-olds in $1761-65(95,6)$. A figure below the former mortality rate was first reached in $1901-05(73,9)$ and below the latter not until 1961-65 $(95,5)$.

In summary one can say of the above that the development of mortality went along different roads in different age groups. In addition one could observe that the spacing of the record lows in mortality differed quite distinctly among the different age groups. As a final conclusion of this analysis one can say that industrialization cannot be considered an immediate cause of the decline in mortality nor can it be used as the only explanation for the changes that occurred. 
Where will we find the causing factors? In my previously mentioned studies (Turpeinen 1972, 1973), where I concentrated especially on regional differentials in mortality and on clarifying its causes, I noted the importance of disease as a factor explaining unusually large regional differences. One may now ask to what extent the development of mortality in different age groups is linked to the development of infectious diseases. To get a good hold on the problem and an exact picture would, of course, require an analysis of the development of the causes of death in different age groups. As the study, which is a part of a larger project, ${ }^{6}$ is still quite incomplete, we will at this point present working hypotheses and additional questions rather than complete answers.

If we examine changes that have taken place in infant mortality and try to unite them with the development of infectious diseases, the first explanation coming to mind would be inoculation, which was begun at the same time as the decline in infant mortality began. If so, should the wide-ranging inoculation begun at the beginning of the 1800 s be considered a secondary factor in the decline of infant mortality? As correct as this explanation sounds, it gives rise, in turn, to some other questions, for example about the development of mortality among 1-2 and 3-4-year-olds. Shouldn't the mortality of these groups also have declined at the beginning of the 1800 s? This did not happen, however, instead these age groups still had very high mortality rate readings in the middle of the $1800 \mathrm{~s}$. Was some contagious disease spreading then, that especially cut down these age groups? A closer examination shows that diphtheria epidemics killed off many children at this time. ${ }^{7}$ But was the death toll centered on those over one year old, were infants saved from this curse and does an increase in mortality caused by diphtheria give a satisfactory explanation to occurrences - these are all questions which have yet to be answered.

In following later development one can see that the marked decline in mortality which began in the last few years of the 1800 s occurred at the same time as discoveries in medicine and their application. One could now, of course, claim that industrialization by creating prosperity helped out in the application of these discoveries and thus indirectly had an effect on the decline in mortality. The cause-and-effect relationships in this case are different, however, than in an explanation based on the claim that industrialization did away with hunger by improving nutrition and thus lowered mortality.

6 The project in question is being carried out under the Humanistic Committee of the Finnish Academy. The project's aim is to examine the structural changes which have taken place in Finnish society since 1750 in the development of crime (Heikki Ylikangas, Ph.D), education (Antero Heikkinen, Ph.D.) and population (Oiva Turpeinen, licentiate of science).

7 Turpeinen $1972,71,87-88$, population change tables $1808-1965$. This was a panEuropean epidemic, which also ranged in Sweden, see G. Utterström, A Outline of some Population Changes in Sweden ca. 1660-1750 and a Discussion of some Current Issues (Population in History, 1965), especially page 546. 
The development of mortality in the more mature age classes is evidently linked to the development of infectious diseases. It is quite probable that the long-lasting high level of mortality among young working-aged people is connected at least partially to the course taken by tuberculosis (BackmanSavonen 1934 and Härö-Pätiälä 1958). Here, too, the phenomenon is apparently connected indirectly to industrialization, which caused young people, especially, to move to the cities and centers of population, but at the same time all the contacts these people had with others created good ground for the spread of tuberculosis. Thus, on the one hand, industrialization apparently indirectly increased the spread of tuberculosis and hampered the intense fight against it, but, on the other hand, it created the material basis from which it could be brought under control.

From the above one can see that the relationship between industrialization and the decline in mortality is a very intricate complex. It is not possible to connect these two phenomena into a direct cause-and-effect relationship. Now, of course, another question comes to mind: is possibly another important period of transition in the history of man - from nomadic life to agriculture - equally as complicated when it comes to this question. It is generally felt that the very reason for the increase in population in the different parts of the world at this stage was the transition to a new way of life, agriculture, which would then have caused a decline in mortality and provided the necessary conditions for population growth. (Reinhard, Armengaud \& Dupaquier 1968, 15 and Cipolla, 1968). It is plain that in discussing such early phases, on which source material is minimal and also very one-sided, conclusions can be no more than mere suppositions. One way to find some sort of support for different hypotheses is to study later times - on which statistics are available - and the mortality reigning in the peripheral areas among the nomads, on the one hand, and the permanent inhabitants, on the other. A study like this, although with a different problem statement, was completed by Sten Wahlund, (1932), a Swede, who in his doctoral thesis analyzed the development of mortality in four parishes in Northern Sweden (Karesuando, Jukkasjärvi, Jokkmok, Gallivare) from the end of the 1700 s to the middle of the 1800 s among both the Lapps and the permanent inhabitants. ${ }^{8}$ He noticed that mortality among the nomads was noticeably higher than among the permanent inhabitants. For example, in the 0 -5-year-old age group the mortality rate among the nomads was 101,0 in $1791-1840$, but among the latter it was only 81,0 . The differences in infant mortality are even larger: in 1800 44 the reading for the nomads was 259 , while for the settled inhabitants it was 132 (Wahlund, pp. 57, 78-79, 117). Wahlund does not attempt to find an answer to these enormous differences. One may now ask, however, whether this

$8 \mathrm{~J}$. Hellstenius found similar results at the end of the 1800 s, see his study $\gg$ Barndödligheten i Vesternorrland och Jemtlands län» (Statistisk Tidskrift 1884), pp. 156-161, 167-68. In explaining the results Hellstenius points to racial factors. 
phenomenon could also be explained by the vast might of infectious diseases. Nomadic life provided an excellent opportunity for the spread of such diseases, while permanent settlement isolated people more. Therefore the assumption can be made that the transition from one industry to another created the necessary conditions for a decline in mortality and growth in population. If such is the case, then the transition from the nomadic level to agriculture should be regarded in a somewhat different light than heretofore. One can agree to a great extent with Henschen, the Swedish researcher, that it is really a miracle that man did not become extinct in the epidemics which raged during man's long prehistory (Henschen 1962, 28). ${ }^{9}$ In this sense the transition to agriculture meant man's »delivery» and protection against infectious diseases.

Evidently little attention was paid to this change in the transitional phase, because knowledge about diseases and especially their causes was very slight. Not until recent times and, above all, by the tremendous increase in knowledge in this field, also, which has taken place in the last hundred years, has the systematic fight against infectious diseases been made possible.

However, this development cannot be examined only as a result of man's conscious - or even unconscious - activity. The decline in mortality and the growth of population in Europe - and this can be clearly seen in Finland, too - began already before the middle of the 1800 s. The reasons for this phenomena are for the main part still shrouded in mystery; however, efforts to connect the beginning of this change to economic factors have not been successful in a universally satisfactory way. On the contrary, the idea has been expressed that the decline in mortality began when the plague began to disappear, which in turn was due to factors not at all economic. (Helleiner 1965, $79-86){ }^{10}$

In summary of the above it can be said that the connection between economic factors and population growth is more ambiguous than research has till

9 Although Henschen's idea is more a semi-speculative hypothesis than a scientific conclusion, it is worth paying attention to. For in my understanding population historians have interpreted occurrences too much in the Malthusian spirit as meaning that hunger acts as a check on supposedly surplus population. This logical explanation leaves out man's conscious activity, and in fact explains nothing, because according to the theory the ssurplus» part of the population always dies off. - However, there evidently was, for example, conscious planning of family size even in preindustrial times. For more on the problem and literature see e.g. Oiva Turpeinen, Norden och den befolkningshistoriska forskningen (Historisk Tidskrift för Finland 1/1976).

10 On the other hand it can be assumed that the evident decline in mortality at the beginning of the $1700 \mathrm{~s}$, which was certainly caused in part by the collapse of the power held by the plague, was possibly an important basic factor in industrialization. For if the plague would have continued to be as wide-spread as it had been previously, it would have caused endless destruction in the densely settled industrial centers. If such was the case, then the causal relationship between industrialization and mortality must be seen in a quite different light than we have been accustomed to up till sow. 
now led us to believe. This implies also that even before the transition to agriculture a much larger number of people may have lived on earth than is usually claimed, but this population has been wiped out by epidemics time and time again to only a fraction of its former size. Similarly the populations of latter-day agricultural communities may have risen to much higher numbers than those presented by 20th-century population historians. In other words, the graph which is often presented nowadays, showing the quantitative development of world population, progressing almost horizontally for a long time and then just during the last few centuries rising more and more frantically upwards and which is mainly based on the hypothesis that economic factors and population growth are tightly linked throughout history, may after all be for the most part - except for the very last part - pure fiction.

\section{References}

Backman, W. \& Savonen, S. Keuhkotaudin kulku Suomessa vuosina 1771-1929. 1934. Cipolla, C. Världens befolkningsutveckling i ekonomisk-historisk belysning. 1968.

Dray, M. Population and Society in Norway. 1969.

Eversley, D. E. C. Population. Economy and Society. In Population in History (Ed. by Glass, D. V. and Eversley, D. E. C.). 1965.

Griffith, G. T. Population Problems of the Age of Malthus. 1926.

Helleiner, K. F. The Vital Revolution considerad. In Population in History (Ed by Class, D. V. and Eversley. D. E. C.). 1965.

Hellstenius, J. Barndödligheten i Vesternorrland och Jemtlands län. In Statistisk Tidskrift. 1884.

Henschen, F. Sjukdomarnas historia och geografi. 1962.

Härö, A. S. - Pätiälä, J. Tuberkuloosikuolleisuuden ja -sairastavuuden kehityksestä Suomessa ja Helsingissä vuosina 1900—1956. In Duodecim 1958, pp. 677-702.

Imhof, A. E. and Larsen, Ø. Sozialgeschichte und Medizin. 1975.

Jutikkala, E. - Kauppinen, M. The Structure of Mortality during Catastrophic Years in a Pre-industrial Society. In Population Studies. Journal of Demography, Vol. XXV, No. 2, 1971.

Kaukiainen, Y. Miksi kansa lisääntyi. Historiallinen Aikakauskirja 2/1973.

Marshall, T. H. The Population Problem during the Industrial Revolution. Econ J. Suppl., January 1929.

Pitkänen, Kari, Kadonneet sielut. Väestö- ja väestönmuutoksia kuvaavien lähteiden luotettavuudesta Kiteen ja Rääkkylän seurakuntien lähtieiden perusteella (Pro-gradu dissertation in Finnish History), Univ, of Helsinki. 1975.

Population and Economics. Proceedings of Section V of the Forth Congress of the International Economic History Association (ed. by Deprez, P,). 1968.

Population in Industrialization (ed. by Drake, M.) 1969.

Reinhard, M. R. - Armengaud, A. - Dupaquier, J. Histoire Générale de la Population Mondiale. 1968.

Statistical Central Bureau. Väkiluvuntilastoa VI, 1-104, especially 29, 33 and 41.

Strömmer, A. Väestöllinen muuntuminen Suomessa. 1969.

Tranter, N. L. Population since the Industrial Revolution. 1973.

Turpeinen, O. Kainuun väestöolot ja niihin vaikuttavat tekijät vv. $1890-1910.1967$ Licentiate Study, Univ. of Helsinki 1969.

Turpeinen O. Suomen väestöolot vuosina $1816-65$ (1972, mimeograph). 
Turpeinen, O. Regional Differentials in Finnish Mortality Rates 1916-1965. In Scandinavian Economic History Review. 1973, pp. 143-163.

Turpeinen O. Ikäryhmittäinen kuolleisuus Suomessa vv. 1751-1970. Demometrinen selvitys $(1973 \mathrm{~A})$.

Turpeinen, O. Norden och den befolkningshistoriska forskningen. In Historisk Tidskrift för Finland 1/1976.

Wahlund, S. Demographic Studies in the Nomadic and Settled Population of Northern Lapland. 1932.

Winberg, Ch. Folkökning och proletarisering. 1975.

Utterström, G. An outline of Some Population Changes in Sweden ca. 1660-1750 and a Disscussion of Some Current Issues. In Population in History (Ed by Glass. D. V. and Eversley, D.E.C.). 1965. 
A ppendix Age-specific mortality rates in Finland in five-year period in the

Per 1000 persons of the average

\begin{tabular}{|c|c|c|c|c|c|c|c|c|c|}
\hline $\begin{array}{l}\text { Five-year- } \\
\text { period }\end{array}$ & $\begin{array}{l}\text { Infant } \\
\text { mortality } \\
\text { rate }\end{array}$ & $1-2$ & $3-4$ & $5-9$ & $10-14$ & $15-19$ & $20-24$ & $25-29$ & $30-34$ \\
\hline $1751-55$ & 223,2 & 51,8 & 24,4 & 12,4 & 5,9 & 5,2 & 6,5 & 7,1 & 9,8 \\
\hline $1756-60$ & 224,8 & 57,0 & 26,6 & 14,2 & 5,6 & 6,0 & 6,8 & 7,7 & 10,2 \\
\hline $1761-65$ & 246,6 & 70,5 & 35,1 & 17,4 & 6,7 & 5,8 & 7,5 & 8,6 & 11,5 \\
\hline $1766-70$ & 235,1 & 53,8 & 25,8 & 13,6 & 6,1 & 5,9 & 7,0 & 8,1 & 9,9 \\
\hline $1771-75$ & 201,2 & 37,6 & 16,8 & 8,9 & 4,5 & 5,1 & 7,1 & 8,1 & 9,9 \\
\hline $1776-80$ & 217,3 & 56,3 & 25,8 & 14,0 & 5,7 & 5,2 & 6,5 & 7,2 & 8,1 \\
\hline $1781-85$ & 218,0 & 64,3 & 33,8 & 16,1 & 6,5 & 5,6 & 6,5 & 7,5 & 8,8 \\
\hline $1786-90$ & 213,3 & 63,3 & 29,8 & 16,0 & 7,1 & 8,1 & 11,5 & 13,9 & 16,2 \\
\hline $1791-95$ & 211,5 & 74,4 & 35,3 & 20,2 & 7,8 & 6,5 & 7,9 & 9,0 & 10,6 \\
\hline $1796-00$ & 197,7 & 53,0 & 26,6 & 12,2 & 4,8 & 4,5 & 5,0 & 6,3 & 7,5 \\
\hline $1801-05$ & 194,9 & 53,9 & 27,7 & 14,8 & 5,1 & 4,9 & 5,8 & 6,7 & 8,3 \\
\hline $1806-10$ & 234,1 & 74,0 & 43,9 & 23,7 & 11,2 & 10,4 & 12,1 & 14,2 & 17,4 \\
\hline $1811-15$ & 207,6 & 67,2 & 30,4 & 15,9 & 6,8 & 6,1 & 6,9 & 7,8 & 8,5 \\
\hline $1816-20$ & 194,8 & 55,3 & 26,0 & 13,1 & 5,5 & 5,4 & 7,1 & 7,5 & 9,1 \\
\hline $1821-25$ & 202,3 & 58,1 & 26,6 & 13,6 & 5,9 & 5,4 & 6,8 & 7,6 & 8,5 \\
\hline $1826-30$ & 202,4 & 49,3 & 21,1 & 10,4 & 4,9 & 5,1 & 6,5 & 8,0 & 9,4 \\
\hline $1831-35$ & 211,6 & 64,5 & 35,0 & 20,4 & 9,6 & 8,6 & 10,0 & 10,4 & 13,1 \\
\hline $1836-40$ & 189,8 & 51,9 & 24,1 & 13,0 & 6,3 & 5,7 & 7,2 & 8,2 & 9,6 \\
\hline $1841-45$ & 177,5 & 46,2 & 21,3 & 10,3 & 4,8 & 4,7 & 6,3 & 7,0 & 7,8 \\
\hline $1846-50$ & 179,9 & 52,0 & 23,3 & 11,2 & 5,0 & 5,3 & 7,3 & 8,1 & 9,1 \\
\hline $1851-55$ & 175,6 & 65,6 & 34,0 & 17,2 & 7,8 & 6,7 & 8,4 & 9,7 & 10,7 \\
\hline $1856-60$ & 185,2 & 64,2 & 34,0 & 16,5 & 7,3 & 7,3 & 9,7 & 10,4 & 11,6 \\
\hline $1861-65$ & 179,1 & 70,1 & 33,4 & 14,1 & 5,7 & 5,4 & 7,2 & 7,6 & 8,6 \\
\hline $1866-70$ & 211,7 & 74,2 & 46,5 & 22,7 & 10,3 & 9,5 & 12,3 & 14,6 & 17,3 \\
\hline $1871-75$ & 170,2 & 54,4 & 21,6 & 9,1 & 4,6 & 5,2 & 7,0 & 7,5 & 8,4 \\
\hline $1876-80$ & 163,2 & 54,9 & 23,9 & 10,5 & 5,1 & 5,5 & 7,0 & 7,7 & 8,5 \\
\hline $1881-85$ & 161,5 & 53,1 & 26,2 & 11,6 & 5,0 & 5,5 & 6,9 & 7,2 & 8,0 \\
\hline $1886-90$ & 143,8 & 43,5 & 18,6 & 8,3 & 4,4 & 5,0 & 7,0 & 7,4 & 8,2 \\
\hline $1891-95$ & 145,0 & 47,6 & 22,0 & 10,0 & 4,9 & 5,4 & 7,3 & 6,6 & 8,2 \\
\hline $1896-00$ & 138,8 & 39,2 & 17,1 & 8,3 & 4,6 & 5,4 & 7,2 & 7,1 & 7,6 \\
\hline $1901-05$ & 131,0 & 36,6 & 17,4 & 8,8 & 5,2 & 6,0 & 7,4 & 7,7 & 7,8 \\
\hline $1906-10$ & 117,0 & 32,3 & 14,7 & 7,7 & 4,7 & 6,0 & 7,3 & 7,6 & 7,8 \\
\hline $1911-15$ & 110,0 & 26,7 & 11,3 & 5,8 & 4,2 & 6,0 & 7,4 & 7,6 & 7,8 \\
\hline $1916-20$ & 113,9 & 35,0 & 15,4 & 7,8 & 5,1 & 9,4 & 14,9 & 13,6 & 12,9 \\
\hline $1921-25$ & 96,6 & 19,7 & 6,7 & 3,7 & 3,5 & 5,4 & 7,7 & 7,2 & 7,2 \\
\hline $1926-30$ & 87,9 & 16,0 & 5,4 & 3,3 & 3,2 & 5,6 & 7,9 & 7,5 & 7,4 \\
\hline $1931-35$ & 72,2 & 12,2 & 5,0 & 3,1 & 2,6 & 4,4 & 6,2 & 6,1 & 6,3 \\
\hline $1936-40$ & 71,6 & 11,2 & 4,8 & 2,9 & 2,3 & 4,1 & 9,8 & 10,4 & 9,1 \\
\hline $1941-45$ & 61,4 & 9,8 & 5,0 & 3,1 & 2,3 & 6,8 & 19,6 & 13,8 & 11,3 \\
\hline $1946-50$ & 51,9 & 4,7 & 2,3 & 1,4 & 1,2 & 2,6 & 4,4 & 4,4 & 4,4 \\
\hline $1951-55$ & 32,4 & 2,6 & 1,2 & 0,7 & 0,6 & 1,0 & 1,6 & 2,0 & 2,3 \\
\hline $1956-60$ & 24,6 & 2,2 & 0,9 & 0,6 & 0,5 & 0,8 & 1,2 & 1,6 & 2,6 \\
\hline $1961-65$ & 18,8 & 1,3 & 0,7 & 0,5 & 0,4 & 0,8 & 1,1 & 1,4 & 1,8 \\
\hline $1966-70$ & 14,3 & 1,0 & 0,7 & 0,5 & 0,4 & 0,8 & 1,0 & 1,2 & 1,6 \\
\hline
\end{tabular}


years $1751-1970$.

population in the group in question

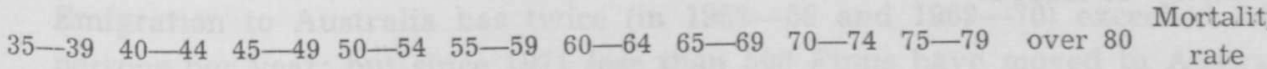

\begin{tabular}{|c|c|c|c|c|c|c|c|c|c|c|}
\hline 10,0 & 14,0 & 14,3 & 19,4 & 25,7 & 36,5 & 49,3 & 74,4 & 103,0 & 163,9 & 28,6 \\
\hline 11,9 & 15,1 & 16,2 & 21,2 & 28,1 & 39,7 & 51,7 & 75,3 & 104,9 & 177,0 & 29,6 \\
\hline 11,8 & 16,2 & 16,1 & 24,2 & 26,2 & 47,3 & 51,3 & 75,0 & 95,6 & 187,7 & 32,4 \\
\hline 11,0 & 15,0 & 16,9 & 21,5 & 29,5 & 40,3 & 54,1 & 84,1 & 104,0 & 182,9 & 28,5 \\
\hline 11,3 & 14,7 & 16,1 & 21,6 & 24,0 & 41,5 & 50,5 & 91,6 & 100,1 & 178,3 & 23,5 \\
\hline 8,7 & 11,6 & 14,3 & 18,3 & 24,3 & 31,6 & 53,6 & 74,3 & 116,3 & 158,6 & 25,8 \\
\hline 9,7 & 12,6 & 14,6 & 19,7 & 25,9 & 38,9 & 50,7 & 87,2 & 111,6 & 203,7 & 27,6 \\
\hline 18,8 & 24,0 & 28,6 & 34,0 & 42,0 & 58,8 & 76,1 & 103,6 & 153,1 & 223,7 & 32,3 \\
\hline 11,6 & 14,6 & 16,4 & 21,5 & 27,9 & 43,6 & 56,5 & 91,2 & 103,8 & 195,6 & 29,3 \\
\hline 8,6 & 11,1 & 13,6 & 17,8 & 24,9 & 39,0 & 57,8 & 88,9 & 127,6 & 186,7 & 23,9 \\
\hline 9,4 & 11,5 & 13,7 & 19,9 & 27,1 & 40,8 & 58,2 & 94,7 & 129,1 & 210,6 & 24,8 \\
\hline 20,8 & 26,5 & 32,3 & 44,4 & 57,1 & 79,0 & 107,4 & 146,0 & 215,9 & 319,9 & 38,2 \\
\hline 10,9 & 14,3 & 16,7 & 23,7 & 32,7 & 48,8 & 67,4 & 104,6 & 148,9 & 253,6 & 26,8 \\
\hline 10,8 & 12,9 & 16,2 & 22,0 & 30,9 & 46,8 & 68,2 & 103,8 & 146,0 & 230,0 & 25,1 \\
\hline 10,3 & 13,0 & 14,8 & 21,1 & 29,0 & 44,3 & 62,1 & 100,2 & 138,7 & 216,7 & 25,7 \\
\hline 10,3 & 12,8 & 15,7 & 21,0 & 29,1 & 42,3 & 63,9 & 95,9 & 145,3 & 223,5 & 24,6 \\
\hline 15,6 & 18,0 & 21,6 & 29,9 & 38,7 & 56,1 & 79,6 & 118,4 & 160,4 & 257,2 & 31,4 \\
\hline 12,4 & 15,3 & 17,2 & 23,7 & 33,7 & 48,0 & 68,0 & 102,6 & 144,5 & 224,6 & 25,1 \\
\hline 9,0 & 12,1 & 14,2 & 17,6 & 25,9 & 40,3 & 56,8 & 91,3 & 131,0 & 212,6 & 22,3 \\
\hline 10,9 & 13,3 & 16,7 & 22,5 & 27,6 & 44,3 & 65,2 & 96,5 & 145,3 & 237,2 & 24,6 \\
\hline 12,6 & 14,6 & 17,2 & 23,7 & 33,3 & 47,1 & 70,5 & 109,8 & 159,7 & 265,2 & 28,6 \\
\hline 13,6 & 16,4 & 19,6 & 25,4 & 35,6 & 52,3 & 72,6 & 110,4 & 162,6 & 249,2 & 29,3 \\
\hline 10,0 & 12,1 & 14,7 & 19,2 & 25,7 & 40,8 & 64,2 & 93,3 & 145,5 & 240,3 & 26,2 \\
\hline 21,4 & 28,9 & 36,2 & 46,8 & 58,8 & 76,5 & 113,6 & 160,6 & 210,2 & 298,3 & 38,6 \\
\hline 9,3 & 10,1 & 12,0 & 16,0 & 22,8 & 35,2 & 51,4 & 85,3 & 131,8 & 202,1 & 21,7 \\
\hline 9,8 & 11,2 & 12,9 & 17,4 & 24,6 & 37,2 & 54,4 & 88,1 & 132,4 & 211,1 & 22,7 \\
\hline 8,9 & 10,4 & 12,0 & 16,1 & 22,3 & 33,8 & 53,0 & 82,4 & 130,4 & 212,5 & 22,2 \\
\hline 9,3 & 10,5 & 12,2 & 15,5 & 22,4 & 32,6 & 50,7 & 79,7 & 124,1 & 203,6 & 20,0 \\
\hline 8,5 & 10,2 & 12,0 & 16,4 & 21,4 & 31,0 & 52,3 & 82,6 & 128,7 & 204,9 & 20,6 \\
\hline 8,4 & 9,4 & 10,9 & 14,7 & 20,5 & 28,5 & 46,3 & 76,6 & 118,4 & 196,2 & 19,3 \\
\hline 8,4 & 9,3 & 10,9 & 14,4 & 20,3 & 30,0 & 45,4 & 73,9 & 115,4 & 192,8 & 19,2 \\
\hline 8,7 & 9,7 & 11,1 & 14,5 & 19,8 & 30,1 & 44,9 & 70,0 & 111,7 & 191,9 & 18,2 \\
\hline 8,3 & 9,5 & 11,7 & 14,7 & 20,7 & 30,0 & 45,3 & 71,0 & 112,2 & 204,8 & 17,1 \\
\hline 12,9 & 13,6 & 15,3 & 18,2 & 24,7 & 34,1 & 50,6 & 79,8 & 122,2 & 210,2 & 20,8 \\
\hline 7,7 & 9,0 & 11,3 & 14,5 & 20,7 & 30,0 & 44,8 & 69,2 & 108,7 & 182,4 & 15,1 \\
\hline 7,9 & 9,2 & 11,2 & 15,5 & 20,9 & 30,5 & 45,2 & 68,4 & 102,7 & 172,4 & 14,8 \\
\hline 7,0 & 8,5 & 10,5 & 14,3 & 20,3 & 29,8 & 44,9 & 66,4 & 103,4 & 166,1 & 13,4 \\
\hline 8,9 & 9,0 & 10,2 & 14,4 & 20,8 & 30,7 & 46,2 & 71,2 & 110,4 & 185,2 & 14,9 \\
\hline 9,6 & 9,0 & 10,0 & 13,4 & 19,3 & 28,6 & 42,7 & 65,2 & 104,1 & 176,3 & 16,1 \\
\hline 4,7 & 5,8 & 8,2 & 12,1 & 17,6 & 26,7 & 40,8 & 63,7 & 98,0 & 176,3 & 11,7 \\
\hline 3,0 & 4,2 & 6,4 & 10,0 & 15,5 & 24,3 & 38,5 & 61,4 & 101,0 & 190,0 & 9,5 \\
\hline 2,7 & 4,0 & 5,8 & 9,3 & 14,4 & 22,5 & 35,9 & 58,3 & 95,6 & 180,9 & 9,0 \\
\hline 2,5 & 3,8 & 5,9 & 9,3 & 14,5 & 22,5 & 35,7 & 58,3 & 95,5 & 189,5 & 9,4 \\
\hline 2,5 & 3,8 & 5,9 & 9,0 & 14,0 & 21,8 & 34,4 & 56,0 & 92,6 & 182,6 & 9,7 \\
\hline
\end{tabular}

